\title{
Administrator Insights, Evaluation, and Support of New Teacher Use of Educational Technology
}

\author{
Heather Donnelly \\ Illinois State University. E-mail: hjdonne@ilstu.edu \\ Lydia Kyei-Blankson (corresponding author) \\ Illinois State University. E-mail: 1kyeibl@ilstu.edu
}

Received: September 25, 2014 Accepted: October 11, 2014 Published: December 2, 2014

doi:10.5296/jet.v2i1.6719 URL: http://dx.doi.org/10.5296/jet.v2i1.6719

\begin{abstract}
Since the advent of educational technology educators have been faced with the challenge of transforming instruction with the goal of providing significant experiences that match $21^{\text {st }}$ century learner needs. While training and professional development have been offered to help prepare teachers, research suggests the continued existence of a digital divide even among new teachers who move from the pre-service stage into the classroom. This is a cause for concern. The question is what are administrators' thoughts on this issue and what types of educational resources and support are provided to help new teachers in order to help them feel more ready to integrate technology in their teaching when they enter into school employment? The purpose of this qualitative study is to explore principals' insights on new teacher preparedness to integrate technology and examine the ways in which schools are providing support to help novice instructors meet the International Society for Technology in Education (ISTE) National Educational Technology Standards (NETS) and Performance Indicators for Teachers. The results of this study have implications for the training of teachers, and the development and implementation of school and district-wide technology initiatives that promote and support teacher use of educational technology in teaching and learning.
\end{abstract}

Keywords: teacher preparedness, novice instructors, educational technology, professional development

\section{Introduction}

As society continues to become more technology-literate, the expectation has shifted from PK-12 educators having a general knowledge in computer use to having more expertise in how to effectively integrate educational technology in teaching and learning. According to the 
2000 International Society for Technology in Education (ISTE) National Educational Technology Standards (NETS) and Performance Indicators, classroom teachers need to be able to:

1) Demonstrate a sound understanding of technology operations and concepts

2) Plan and design effective learning environments and experiences supported by technology

3) Implement curriculum plans that include methods and strategies for applying technology to maximize student learning

4) Apply technology to facilitate a variety of effective assessment and evaluation strategies

5) Use technology to enhance productivity and professional practice.

6) Understand the social, ethical, legal, and human issues surrounding the use of technology in PK-12 schools and apply that understanding in practice (p.9)

In order to meet the shifting challenge, a wealth of resources has been directed towards educating prospective teachers on the appropriate use of technology in the classroom as there still remains an inconsistency in what is expected and what is actually being done in the classroom (Cuban, Kirkpatrick, \& Peck, 2001; Mayo \& Kajs, 2005). Much has been written on how to prepare new teachers on appropriate ways to integrate technology in a manner that meets the NETS and professional indicators. However, very little has been said about this issue from the school administrators' viewpoint. It is important to understand how the administration evaluates and supports teacher preparedness to use technology in teaching and learning. Research presented by the National Center for Education Statistics (NCES) (2000) suggests that the school administrator is influential when it comes to the availability and accessibility of technology for teaching and learning and so it is important to explore what their views and role is the integration of technology instruction. The school administrator is in charge of evaluating teachers and so it is only right to seek their insights on teacher preparedness and use of technology and how they encourage and support new teachers in their quest to use technology in instruction.

In this qualitative study, educational administrators' views on new teacher preparedness to integrate technology and what can be done to better prepare and support new teachers are explored. In addition, the study looks at strategies and school policies and procedures that have been put in place in schools to provide a supportive environment for new teacher technology use. This research attempts to answer the following research questions:

1) What are educational administrators' views on new teacher preparedness to use technology and are there connections between school demographics and teacher technology integration patterns?

2) What strategies, policies, and procedures are put in place in the schools to evaluate new teachers' use of technology and promote a supportive educational environment 
to ensure successful integration of technology in instruction in a manner that meets ISTE NETS?

This study is important as it provides administrator views while contributing to the general literature on teacher use of educational technology. Teacher education programs may find the results of this study useful when making strategic decisions concerning modeling technology use, curriculum choices, and program requirements in the area of technology.

\section{Review of the Literature}

The following literature review presents past research related to the domain of this study. Specific focus is given to the themes of Teacher Technology Preparation in Pre-service Training, Teacher Technology Professional Development, and School Administrators' Role in Teacher Technology Support.

\subsection{Teacher Technology Preparation in Pre-service Training}

As technology continues to have a greater impact on society, there is increased pressure to prepare teachers to not only digitalize their classrooms, but to also utilize technology that is appropriate to the educational context in which they are teaching. Technology courses within teacher education are typically taught separate from subject area methods classes and have focused primarily on the development of digital skills and knowledge with no opportunity for application. New instructors therefore typically enter the classroom with ordinary technological skills and knowledge, but lack the required know-how, as well as the confidence and self-efficacy to integrate technological practices into their teaching models right from the beginning of their instructional careers.

Waring (2010) explains that teachers need to seamlessly integrate digital activities into their lessons and use technology as a tool, rather than the "driving force behind instruction" (p.79). However, teacher education programs have taken a "workshop" approach to incorporating technology, typically requiring students to take one educational technology course. The brief, direct instruction style of this approach reinforces the idea that future teachers will walk away from a one or two-hour educational technology course with limited subject or grade specific application knowledge to use technology as a teaching tool (Waring, 2010). As a result, new teachers would normally have the skills and knowledge to perform administrative duties such as attendance, lunch count, and email communications, but lack the ability to consistently implement digital instruments into their classroom practices (Chen \& Chang, 2010) and in a manner that meets national standards.

More recently, colleges of education have intensified their efforts to integrate technology directly into methods courses, giving students the opportunity to carry out what they have learned (Allsopp, McHatton, \& Cranston-Gingras, 2009). Due to this effort, teacher candidates may show signs of gains in technology comfort levels, but this does not necessarily translate into effective technology use within lesson plans (Mayo \& Kais, 2005). Furthermore, research indicates that teacher education programs have struggled with connecting educational theory to practical application and are continually trying to find best practice solutions for closing this gap (O’Connor, 2006-2007; Darling-Hammond, 2005). 
In 2006, Kay conducted a literature review of 68 journal articles concerning the effectiveness of technology integration into pre-service teacher education programs. In this instance, the reviewed studies integrated information on at least one of ten methods or strategies by which programs deal with educating prospective teachers on how to incorporate technology in their classrooms. These strategies include "integrating technology in all courses; using multimedia technology in teaching; focusing on education faculty; delivering a single technology course; modeling how to use technology; collaboration among pre-service teachers, mentor teachers, and faculty; practicing technology in the field; offering mini-workshops; improving access to software, hardware, and/or support; and focusing on mentor teachers" (Kay, 2006, p. 389). Weaving technology throughout the entire program was the approach used most frequently compared to the other nine strategies. The tactic that was employed the least involved putting the responsibility of technology teaching on a mentor instructor, who would work with the pre-service teacher on a one-on-one basis to educate the future teacher on the use of technology in the classroom. Subsequently, Kay pointed out that when at least one method was used, there were statistically significant gains made in the areas of computer attitudes, ability, and use, and the gains in regards to classroom use increased the most when several strategies were used in combination. In fact, out of the 68 studies evaluated, the three that incorporated four or more learning strategies reported sizable gains in pre-service teacher computer use (Kay, 2006). Although Kay does not deliberately specify which combination supports the greatest gains, it was noted that standout colleges of education use the amalgamation approach including separate technology courses, technology embedded within subject specific methods courses, and the incorporation of digital tools in field experiences.

It can be safely concluded that the advantages of using a variety of learning strategies for different learners (Darling-Hammond \& Bransford, 2005) applies to people of all ages, including post-secondary students. Using a combination of learning strategies may positively impact teacher education students when trying to successfully incorporate technology into their lesson plans. As a variety of strategies are employed, future teachers will grasp different elements of each, thereby reinforcing the multiple uses of technology in PK-12 classrooms.

As Kay (2006) reported, pre-service teacher use of educational technology was influenced by and depended on teacher education strategies. Will effective pre-service use of educational technology translate into use during their use when they enter the classroom? According to Gao, Wong, Choy \& Wu (2010), when beginning teachers start their careers in education, there is an automatic opportunity for them to utilize their generational aptitudes to lead the school in technology integration, as well as take on the role as "change agents" in the transformation of teaching and learning through technology (Gao, Wong, Choy, \& Wu, 2010). Unfortunately, in many cases, Russell, Bebell, O’Dwyer, \& O'Connor (2003) report new teachers are not capitalizing on this opportunity as they were less prepared to do so. In fact, new teachers were found to use technology on a frequent basis for personal purposes outside of the classroom, but implemented technology far less inside the classroom compared to more experienced instructors (Russell, Bebell, O’Dwyer, \& O’Connor, 2003). Although beginning teachers are indicating they have "high levels of confidence," when it comes to implementing educational technology into their practices, research indicates technology is rarely being 
utilized to its fullest extent during a teacher's foundational years (Russell, Bebell, O'Dwyer, \& O’Connor, 2003; Starkey, 2010).

Once pre-service teachers enter the profession, decisions are made daily on the tools used to present learning material, as well as the methods and techniques used by learners in lessons, with the goal of creating an optimal learning experience. Many pre-service teachers come in with a set of skills, knowledge, and ideas regarding technology use, but are still in need of professional development and training in order to keep updated and expand their existing knowledge.

\subsection{Teacher Technology Professional Development}

There is considerable research that supports the idea behind using a more in-depth, all-inclusive approach to the professional development of teachers in the area of educational technology. Short-term, general skills and knowledge training does not lend itself to effective use in the classroom on a consistent basis. Chen and Chang (2006) reinforced this concept by conducting a study that utilized a long-term, all-encompassing technology-training program, which addressed countless issues concerning teachers and instructional technology. The research results revealed that instructors who were exposed to this type of technology training enhanced their skills and knowledge, improved their overall perceptions of classroom technology use, and most importantly, increased their practical use of technology in the educational settings. Departing from stand-alone technology courses to fulfill a requirement or short-lived computer skill workshops, this program prepared instructors to link technological activities to the context of the classroom or subject area (Chen \& Chang, 2006). Chen and Chang (2006) explained, "deemed critical for program success, these core methods included teaching for understanding, cooperative learning, integration with practice, and meeting teachers' instructional needs" (p. 449). These four elements seemed to properly address some of the inadequacies found in other teacher technology training programs. The all-encompassing nature of the program provided ongoing technical and educational support, giving teachers assistance with common issues that would arise after the schooling session was over. Providing guidance and feedback to teachers throughout the learning process, as well as providing the knowledge and skills necessary to integrate educational technology into the early childhood classroom were the common themes that were emphasized throughout the study. Although the above research evaluated early childhood teachers with varying years of experience, the findings and conclusions regarding educational technology professional development may also be applicable to beginning teachers at all levels of education.

Not only is ongoing professional development critical for first-year teachers, but a reliable, consistent technological support network has shown to be beneficial in encouraging novice teacher technology use. Dinh (2009) goes as far as to say, "more technical personnel are required, and some short seminars to train novice teachers to fix simple and most common technical problems, should be part of a district/school's technology plan" (p. 12).

\subsection{School Administrators' Role in Teacher Technology Support}

In this age of accountability the school administrator's role has shifted from one of a manager 
to that of an instructional leader. The instructional leader directs and facilitates instructional quality (Jenkins, 2009) and is responsible for promoting teaching and learning by providing support in various aspects as well as ensuring the availability of professional development (Lunenburg \& Irby, 2006). Specifically, the school administrator, in addition to being in charge of evaluation, is expected to act as the instructional resource when it comes to teaching and learning. Marzano (2003) emphasizes that besides the classroom teacher, the administrator is the next most important factor in ensuring high student achievement.

Given the role administrators play, one cannot overlook their importance in the effective implementation of technology in schools. In a study on teacher perceptions of administrator leadership in technology integration, Rogers (2000) found that teachers who had positive perceptions about their administrator's role in supporting technology integration were more likely to integrate technology themselves. Furthermore, in their study on leadership and technology use in schools, Chang and Hsu (2009) found that administrators who considered themselves technology leaders had a significant and positive influence on teachers' technology use. Anderson and Dexter (2005) also found that leadership is very important in technology integration even more so than the availability of technology infrastructure.

Lunenburg and Ornstein (2008) also reported that school leaders need to supply the resources to help create opportunities for teachers to learn and try new ideas and create an environment that supports school improvement efforts. Research has shown that with a supportive environment and the necessary tools, even novice teachers feel they could take risks with technology, which would enhance instruction and enable them to align their teaching with $21^{\text {st }}$ century curriculum expectations (Williams, Foulger, \& Wetzel, 2009).

While past studies have found that school leadership is an integral component to the success of technology integration in the classroom, not much has been written on the specific strategies and tools that administrators use to support this integration or what changes occur as a result of the support provided for technology integration. School administrators are responsible in many ways for leading their school in effective pedagogy, but their views on technology and teacher technology integration are often overlooked. A comprehensive study of administrator views on technology integration in teaching and learning is therefore recommended. Considering they support teachers in instruction and evaluate teacher performance, administrator views on new teacher technology integration must be examined.

\section{Methods}

In this study, a qualitative approach was used to explore school administrators' insights regarding new teacher preparedness to integrate educational technology. In addition, administrators provided information on what schools and school districts are doing to support new teachers as they plan on integrating technology in their classroom practices. Qualitative research was applied in order to gain a better understanding of the school leader perspectives which are often overlooked.

For this study, purposeful sampling was used to select participants, who were school principals from four middle sized urban grade schools in one central Illinois school district. 
Two female principals and two male principals participated in the study, with each administrator having over ten years of school leadership experience. Purposeful sampling was used when study participants are obligated to fit an explicit criterion in order to reflect the purpose of the study and contribute to an in-depth understanding of the topic (Merriam, 2009). The principals who had some experience mentoring, monitoring, and evaluating new teachers were selected for the study. It is important to note that another criteria that was of interest was the demographics of the administrators' schools; the sample of administrators in this study came from schools with a variety of backgrounds. For instance, the percentage of low-income students in the schools ranged from 4.3 to 27.7 percent below and 5.8 to 13.5 percent higher than the district's average (Illinois School Report Card, 2011).

\subsection{Researcher Positionality}

The first author on this study became interested in the proposed topic during her time as a past teacher education student, and as she moved on and experienced her first year of teaching, her interest level intensified. She began her education career under a new principal who had high expectations regarding the use of technology as part of the educational process. By being the "new person on the block," fresh out of a relatively progressive teacher education institution, she felt the need and desire to meet the principal's expectations. Additionally, she figured education was heading in a digital direction anyway, and it would be wise of her to start off on the right foot and try to get acclimated with as much instructional technology as possible, trying to make it a part of her teaching paradigm right from the beginning. As she reflects on her first year experience, she found that compared to some of her teacher colleagues at the time, she felt completely under prepared and intimidated by educational technology.

As she continued through her first year of teaching, she began thinking about other people's expectations of first year teachers and their use of technology in the classroom. For instance, what were her principal's views on the level of preparation of her and other first year teachers who were to incorporate effective, meaningful technology into their lessons? School administrators must have a standard of performance for the new teachers they hire and undoubtedly have an anticipated mental perception of the skills, knowledge, and qualities that are gained from teacher education programs.

While the second author of this study has no prior K-12 experience, she too has always wondered whether the pre-service teachers in her college as well as other colleges and schools in the United States were adequately prepared to use technology in instruction and has written extensively on the topic of technology use in education. Also, as an instructor in the area of educational administration, she has wondered on the role educational leaders play in teacher evaluation and support when it comes to technology use.

The thoughts and wonderings of the two authors have led to this attempt to explore the administrator views on technology use among new teachers. In addition, the goal is to examine some of the ways administrators support teachers in their quest to use technology in instruction. 


\subsection{Data Collection Approach}

One-on-one interviews, observations during principal-led school tours, and technology-related document analysis were the three qualitative techniques used to collect data for this study. The data was collected in two phases. Phase I involved the collection and analysis of school and district technology-relevant plans and policies. Many of these documents were gathered from the school and district website. In addition, teacher evaluation forms, observational forms and additional documents providing background information and historical context on technology standards and technology planning as suggested by the National Educational Technology Standards (NETS) and published by International Society for Technology in Education (ISTE) were gathered. These documents were used to inform or construct the interview and observation protocols used in the study as well as to "provide background and context, additional questions to be asked, supplementary data, a means of tracking change and development, and verification of findings from other data sources" (Bowen, 2009, p. 30).

Phase II of the study involved two separate in-depth, face-to-face interview, each lasting for about 45 minutes with each principal. The interviews were used to gather information regarding administrator views regarding evaluating teacher educational technology use and the support provided to new teachers. A semi-structured protocol, was chosen in order to explore the issues involved and respond to the participant's answers as the interview unfolded (Merriam, 2009). Questions such as: Can you describe your expectations in general for first-year teachers regarding technology? What has been your experience with novice teacher use of technology? Could you elaborate on how first-year teachers are evaluated in regards to integrating educational technology within their lesson plans? What types of resources are available to first-year teachers as they plan to use technology in instruction? And How are the resources distributed or how are decisions made regarding technology use? were asked of the principals during the interview.

In addition to the interviews, a tour of each school was arranged to observe and document technology resources available in the schools. The school tours were led by each principal. The "walk-through" or tour led to observations of each school's technology resources and facilities and helped provide confirmation of strategies and procedures that have been put in place to support teacher use of educational technology. It is important to note that photographs were taken during the school tour and with the permission of the principals. As described by Patton (1990), observations in qualitative research are "detailed descriptions of people's activities, behaviors, actions, and the full range of interpersonal interactions and organizational process," that take place while observing a particular experience (p. 10). A school tour of the current technology (or lack of) that was being utilized in classrooms, computer labs, and libraries took the place of direct observations of teachers instructing with technology. Considering the study was intended to explore the topic from an administrator's viewpoint and using Patton's (1990) broad description of an observation, the school tour as an alternative to a direct observation seemed appropriate.

The technique of photo-elicitation as described by Harper (2006) was used where the 
"interview/discussion is stimulated and guided" by the images that were being taken (p. 35). Harper (2006) portrays photo-elicitation as an alternative to the open-ended interview, where there is basically a one-way flow of information from the interviewee to the researcher. In this study, photo-elicitation was used to compliment the more traditional data collection technique of interviewing, rather than replacing it altogether. During the school tour, the principals pointed out various aspects of technology available in the school. As the tour progressed, each area and image captured guided the next area of significance. The principals were considered the expert on the topic as they possessed the background information on things such as how the technology is used, when it was purchased, who uses it the most, for what purpose and how the students respond or relate to the use of the technology, etc.

\section{Data Analysis}

Huberman and Miles' (1994) explanation of data analysis as three separate steps closely aligned with the research process of this study. Although this method of data analysis seemed appropriate for the research, as Coffey and Atkinson (1996) repeatedly point out, there is no one particular way to analyze qualitative data. The first step is described as data reduction stage, which in essence involves using the framework of the study to guide the way the data was used, deleted, or expanded. Through this process, questions were refined and purposes were reevaluated in order to properly gather the information necessary to answer the research questions and to follow the intention of the study. The data was then categorized into sub-themes and then larger themes and then finally conclusions and interpretations were drawn from the clusters of themes (Huberman \& Miles, 1994) while focusing specifically on the research questions posed in the study.

Data triangulation as explained by Johnson (1997) was a strategy employed to validate the research. Data was collected from multiple sources including two interviews, the school tours, and by analyzing the technology-related documents gathered from the schools. By using multiple data sources, different perspectives were gathered from the principals as well as from the schools' resources and facilities.

\subsection{Underlying Philosophy: Research Paradigm, Theory, \& Conceptual Framework}

Capper's (1998) analysis of the nature of change and the nature of power from a poststructural conceptual framework aligns well with the methods being used and the questions being asked to gather data. A poststructural perspective views the nature of change, decision-making, power, and the individual as highly personal and completely contingent on the time and space of the situation. This perspective focuses more on the constant reevaluation of reform solutions and decisions made, acknowledging no end point or ideal solution to educational issues, but rather a continual assessment of dissenting opinions, which will hopefully result in more significant change (Capper, 1992). At first glance, educational technology use among new teachers seemed to be a fairly straightforward, objective matter, but with deeper review and analysis, it appeared to have multiple realities depending on the context of the situation and the personalities involved. A postructuralist perspective was used to provide a basis for this research and to give the prospective audience a greater understanding of a relevant, multifaceted educational issue. 
According to Capper (1998), from a poststructural viewpoint, change is viewed as nonlinear, with no specific direction or pattern, which provided the valuable insight for asking questions during the process of the interviews with the administrators. For instance, several of the interview questions used were not designed to have the administrator reach a specific decision in terms of changing their method or approach to monitoring, supporting, or encouraging the use of educational technology amongst new teachers. Rather, the questions were shaped to encourage the principals to acknowledge processes and procedures and realize change in regards to educational technology may take many different forms depending on the circumstances (school, teacher attitudes, students, resources).

In addition to Capper's (1998) analysis of change from a poststructural point of view, he also points out a poststructural view of the nature of power, which shows a strong association to the research questions posed in the study, and how those inquiries are used to guide the study. For instance, when asking the question, "What strategies, policies, and procedures are put in place in the schools to evaluate new teachers' use of technology and promote a supportive educational environment to ensure successful integration of technology in instruction and in a manner that meets the National Educational Technology Standards?, the assumption is that there is a power structure already in place, but that it may be complex and changing, which warrants further elaboration by the participant to explain how power plays out in this particular context (specific schools, classrooms, teachers).

By researching educational technology use of new teachers from an administrative perspective, the concept of leadership became an integral component in trying to understand the dynamic that exist between administrators, teachers, and students regarding the technology used in teaching and learning. As the research project developed and evolved, a formal, substantive theory emerged describing an educational leadership concept called, "transformational leadership." This leadership theory builds on the framework of change (cyclical and continually reevaluated) developed from a poststructural perspective, which emphasizes the poststructural view of power, where power is existing everywhere, possessing complex, dispersed structures rather than appearing in a purely hierarchical format. With transformational leadership, power is distributed equally amongst the leader and the subordinate and both parties are ultimately motivated by a mutually shared purpose, in contrast to transactional leadership, where leaders lead through the exchange of something of value for both parties (similar to a quid pro quo situation) (Burns, 1978). Intrinsic motivational techniques are used in transformational leadership practices, whereas transactional leaders focus more on the promise of extrinsic rewards. Bass (1998) expands on this notion of transformational leadership by contending there are four primary components aligned with this style of guidance: 1.) charismatic leadership, 2.) inspirational motivation, 3.) intellectual stimulation, and 4.) individualized consideration. Additionally, Bass' (1998) view of transformational leadership claims, "transformational practices encourage commitment and foster change," thereby motivating members of the organization to make broad changes that improve school conditions (Stewart, 2006, p. 13). As school conditions improve, school restructuring and reform will automatically take place. 


\section{Results}

At first glance, educational technology use among new teachers seemed to be a fairly straightforward, objective matter, but with deeper review and analysis, it appeared to have multiple realities depending on the context of the situation and the personalities involved. The findings that follow are separated into three sections based on themes developed from the study data and guided by the study research questions. The first section assesses the principals' view of how well prepared new teachers are to effectively integrate educational technology into their teaching practices and whether there were patterns between teacher technology use and a school's demographics. The second section explores the types of methods and techniques that are used by the principal to evaluate and support new teachers in regards to educational technology.

\subsection{Administrator Views on New Teacher Preparedness to Use Technology and Connections to School Demographics}

The administrators included in this study indicated how the new teachers who came into their schools these days are more willing to integrate technology simply because of the generation they belonged to. The principals frequently made references to words such as "young", "comfortable", and "familiar" when they described new teacher readiness to use educational technology. One principal noted:

Overall, most new teachers are very familiar with technology use. They immediately know how to use everything. I don't know if it is being young and knowing how to use technology or if it is an age thing. I think first-year teachers are more aggressive, more apt to learn, and more open-minded by a long shot.

It is important to point out that oftentimes technology capability was not an issue for a new teacher when it came to using it in the classroom. Rather, the concern of the administrator was more connected with the integration of appropriate technology as well as management of the technology use in the classroom, which typically presents more of a challenge for beginning teachers. The principal expressed that new teachers are less capable of having the "wherewithal, for lack of a better word, of knowing how to manage a classroom", suggesting the need for teacher education institutions to offer a course or courses that combine educational technology use with classroom management techniques. A positive and noteworthy point though is that even when the new teacher was observed to be only somewhat prepared to integrate technology, principals observed that the teachers always seemed very eager to jump right in and master the current technology trend. One principal described his views on this by stating:

The new teachers will help each other as well. If they are not using it right away, they will collaborate and most are anxious to try it. This seems to be an area where new teachers can come in... um and take a leadership role. A lot of times they feel they have an edge on this compared to veteran teachers.

Interestingly enough, as the administrators were conducting the walk-throughs and discussing the issue of technology use, the connection between teacher eagerness to use or learn 
technology and age were no longer implied. For instance, one of the principals kept raving mostly about a veteran math teacher who was using technology, specifically Airliner, to teach her Math lesson on the SMART board. The same administrator found it important to include the said veteran teacher's classroom in the walk-through where the teacher was found walking around the room energetically with the pad in her hand communicating verbally and technologically with the students. At one point, she leaned over and a student took the Airliner to compute the problem from his seat. The work showed up on the SMART board and the teacher began to discuss the student's technique.

When it came to exploring the connections between new teacher technology integration and the school's background, one principal felt very strongly about the influence of the socioeconomic status of the school's student population on the approach or methods used by the teacher. She commented on this issue by stating, "It affects their classroom management directly, directly affects whether you are teaching at lower end of Bloom's taxonomy or higher end of Bloom's taxonomy." She goes on to say that a student's economic background can have a significant impact on their ability to grasp knowledge and learn material that is presented in a nontraditional format, simply because many times those lower income students do not have the basic skills associated with technology such as how to appropriately save information, how to create PowerPoints, how to design brochures, or research information adequately. The particular school where this principal was working had a wide spectrum of income levels within the student body. She commented often on the diverse and unique make-up of the families and students at her school, and she ultimately believed this improved technology integration because students were willing to collaborate and help one another with aspects of technology that were challenging to them. However, it was disturbing the way students of low-income backgrounds were referred to and the assumption was made that they will find it difficult to grasp concepts due to their backgrounds.

\subsection{Evaluation Methods, Strategies, and Techniques for Supporting New Teacher Technology Use}

The first two principals interviewed for the study alluded to how there was no formal, or set strategy for assessing technology use among teachers, whereas the last two explained their district's formal evaluation process for new and returning teachers. The principal who described the district evaluation program with the most detail revealed:

The instrument that is used for the evaluation, there's a rubric and there are four domains: domain one being planning and preparation and so there's a component in domain one that asked knowledge of resources. This teacher should be seeking out technology and other resources to be able to use in the classroom, and this domain is looking at simply how it is planned. You know... what's this teacher pulling together to be able to teach?

The administrator was describing a new system that is used for evaluating effective teaching in general and not specifically for the evaluation of technology use. This new system, the Danielson Framework is divided into four domains of evaluation of teaching: Planning and Preparation, The Classroom Environment, Instruction, and Professional Responsibilities (Danielson, 2007). 
One principal did reveal that he did have a self-developed questionnaire that was given to teachers before their evaluation, which referred to educational technology use. He insisted that it was really something (using educational technology) they worked on together, but in the end it was up to the teacher to make time to register for the training and actually try something new in their lessons. This same administrator acknowledged that the level of support provided by the school and the district, which included a wide variety of professional development opportunities, is adequate for new teachers because in his opinion, they have the opportunity "to learn any piece of technology that is available to them."

All four principals felt the evaluation system used to monitor technology use was fair, effective, and reasonable. One particular principal specifically emphasized the "fairness" aspect of the assessment process stating:

I think that a lot of work has gone into creating a tool that is fair and the feedback says it is really good in terms of fairness. The one thing it does is put both sides of the table at the same place. It used to be I would go in take some notes totally on my observation... and this creates a cycle that begins in the first week of school of sitting down with the teacher and outlining the whole year and this very stringent cycle of conversations and observations are all built around goals.

When asked if they were aware of the International Society for Technology in Education's (ISTE) National Education Technology Standards (NETS) for Teachers and whether they used this as a guide for evaluation, it came as a surprise that most of the principals did not show any awareness of this. One principal was almost taken by surprise to the point of being defensive and irritated when these guidelines were mentioned. His curtness was revealed in the following response:

We have no idea what those even are. I mean the district may have some sort of standards they go by, but we don't use those. We may unintentionally follow those, but the technology is driven by what the teachers have available to them. We just don't have time to have those in front of us everyday.

Analysis of the documents such as the district's technology goals/objectives and standards provided a better understanding of the technology climate within the district, where all four principals were employed. An analysis of the documents showed that the ISTE NETS were repeatedly referred to and used as the primary framework to define the district's technology initiative. It was therefore shocking that the administrators had no knowledge of these evaluation requirements or standards. With this being said, a second principal interviewed responded with confidence when she explained:

There are no expectations really for technology in our district as far as knowing how to use certain technologies. When I interview them, I ask them what their experience is with using technology, but being evaluated on it there are no specific targets or checks.

This principal later commented on the inconsistencies in support and technical resources available to the teachers across the district, and this may be the reason for the district not having a concise, coherent technology plan that outlines specific standards for teacher use of 
technology. Indeed it came as a surprise that all four principals were clearly unaware of the Instructional Technology section within their own district's website and also showed a general lack of knowledge of the national technology standards, expressing little knowledge of their existence and their functionality.

More noticeable was the apparent disconnect and lack of unity between the district and the school principals' ideas regarding technology goals, resources, and standards for evaluation. It would seem the classroom teachers would ultimately be the ones who were at a disadvantage, considering there was not an understandable, consistent technology plan across the district, or even at the respective schools.

While the principals did not focus much on the ISTE NETS, they still spoke on the importance of technology use and pointed out ways that the district and their building supported teachers in this endeavor. The school or administrators' support in technology application in teaching and learning was evident during the school walk-throughs. The amount of evidence gathered from the building documents and photographs taken during the observation phase of the study revealed that indeed a variety of technology was made available and accessible to all teachers. Technology such as SMART boards, Airliner, desktop computers, graphing software, document cameras, printers, projectors, iPads, and LEGO Robotics, to name a few, were notable technology available and accessible to the teachers (See appendix). All four principals encouraged technology use in their schools and among their teachers especially the ones new to the field but it is important to point out that there needs to be more done than only providing a list of technology and encouraging their use. Professional development needs to be supported as well, and more essentially, principals need to make sure the technology was being used in line with the ISTE NETS. For this to happen, it is essential for the administrators to have a deep understanding of NETS and its importance for promoting technology integration in schools.

\section{Conclusion}

While the administrators perceive an eagerness among new teachers to integrate technology in their teaching, they also noted that this did not necessarily translate into the use of appropriate technology. However, the concern that arises is how could administrators determine that the use of technology was not necessarily appropriate when there didn't appear to be a formal method for evaluating technology use? And even in cases where a system for evaluation existed, it was connected to the general system of evaluation and not necessarily connected to the National Education Technology Standards that have been put in place to serve as the guiding principle for technology use (U.S. Department of Education, 2010). Coupled with this, school principals who need to be the leaders of the schools and provide effective leadership processes to motivate, inspire, and stimulate new teachers to embrace educational technology themselves seem to lack awareness in this all important area. School leaders need to realize how power in the principal/teacher relationship is constantly evolving and oftentimes situational; therefore making technology decisions based on context and individual considerations will promote positive change.

The study findings reveal the importance of school principals providing an environment where there is clear knowledge and communication of expectations that are consistent within 
the school and across schools in the district. Gao, Wong, Choy, \& Wu, (2011) emphasize a need for coordination and cooperation among all levels of educational professionals by reiterating that district administration, principals in schools, and classroom teachers need to be working toward a "shared vision" of utilizing educational technology to enhance teaching and learning. The importance of "everybody being on the same page," was also expressed by Starkey (2010), reiterating how, "school policies and structures should align with the school's articulated values about the place of digital technologies in teaching and learning processes and pedagogical practices" (p. 1437).

Additionally, principals need to be concerned with the quality and level of support they are giving new teachers, considering the additional challenges novice teachers face such as classroom management, mastery of content, and application of pedagogy when entering the classroom during their first year. More often than not, novice teachers are working through an enculturation process within a multifaceted context, which influences their decisions regarding the use of educational technology (Starkey, 2010). This means, principals need to do more than occasionally "checking in," by promoting school leaders to get people excited about new ways of teaching and learning with technology, while encouraging staff to buy into technological advancements in education. By embracing the notion of transformational leadership as outlined by Bass (1998), and by focusing on the last component associated with the model of transformational leadership: individualized consideration, principals would do a better job of paying attention to their followers' needs and individual stages of development. Considering novice teachers often go through an acclimation process and are preoccupied with more pressing issues during their first year, the importance of effective, personalized leadership approaches are even more critical when fostering an environment for novice teachers to utilize educational technology from the start. By promoting an environment where new teachers can take risks and be creative, principals are encouraging instructors to expand their horizons and broaden the scope of their pedagogic toolbox, enabling them to reach a wide spectrum of learners (Gao, Wong, Choy, \& Wu, 2010).

Lastly, administration and school officials alike need to implement policies that "level the playing field" so to speak, in regards to the availability of technological resources and training, giving each school in a district the opportunity to achieve and be inspired by district wide technology programs. Although age, technology aptitude, and open-minded attitudes of new teachers generally leads to acceptance of educational technology use, principals need to be careful creating an environment where the perception is that young, "tech savvy" teachers are the only instructors able to effectively use technical/digital resources. Even teachers at the end of their career or ones that have been doing this for a while, such as the veteran math teacher using the Airliner, need to be applauded and used as a role model when using technology to better their instruction. Starkey (2010) argues that when a beginning teacher "had a sense of agency and access to a mentor with whom they could discuss the use of digital technologies in the particular subject areas, they were more likely to be innovative and overcome barriers to the use of digital technologies in their teaching practice" (p. 1435).

Overall, the information that was gathered from this research revealed relevant scenarios, concerns, and realities that occur as school leaders (principals) confront issues associated 
with the integration of educational technology by first-year teachers. By following a more transformational style of leadership, school principals can encourage new teachers to implement pioneering classroom concepts and strategies, while taking advantage of their novice status to try something new and be a leader in the area of educational technology. Sustained technology integration can be achieved when principals become leaders for technology integration. As Flanagan and Jacobsen (2003) note a major challenge for administrators is to support teachers in the meaningful integration of technology. And even before administrators are able to provide such support, administrators themselves need to be well-grounded in their knowledge on how to use technology. In this study, the lack of informed leadership was observed when it came to the evaluation and support of teachers as they used technology. The existing body of literature regarding technology integration and the role of administrators supports need for administrators to have knowledge of the National Educational Technology Standards (NETS) as established by the International Society for Technology in Education (ISTE). According to Pritchard (2014), administrators must use the NETS as a guide for evaluating and promoting or supporting technology integration in the K-12 setting. Again, among other things, administrators must undergo technology professional development to ensure that they have the right background to evaluate and support teacher use of technology in the classroom.

\section{References}

Allsopp, D. H., McHatton, P. A., \& Cranston-Gingras, A. (2009). Examining perceptions of systematic integration of instructional technology in a teacher education program. Teacher Education and Special Education, 32(4), 337-350.

Anderson, R., \& Dexter, S. (2005). School technology leadership: An empirical investigation of prevalence and effect. Education Administration Quarterly, 41(1), 49-82.

Bass, B. (1998). Transformational leadership: Industry, military, and educational impact. Mahwah, NJ: Erlbaum Associates.

Bowen, G. A. (2009). Document analysis as a qualitative research method. Qualitative Research Journal, 9(2), 27-40.

Burns, J. M. (1978). Leadership. New York: Harper and Row.

Capper, C. A. (1992). Otherist postructuralist theory and educational administration. Organizational Theory Dialogue, 1, 5-9.

Capper, C. A. (1998). Critically oriented and postmodern perspectives: Sorting out the differences and applications for practice. Educational Administration Quarterly, 34(3), 354-379.

Chang, I., \& Hsu, C. (2009). Research on the path of the influence of principals' technology leadership on teachers' information technology literacy in metropolitan elementary schools. Journal of Elementary Education, 33, 1-32.

Chang, I., \& Hsu, C. (2009). Research on the path of the influence of principals' technology 
leadership on teachers' information technology literacy in metropolitan elementary schools. Journal of Elementary Education, 33, 1-32.

Chen, J., \& Chang, C. (2006). Using computers in early childhood classrooms: teachers' attitudes, skills and practices. Journal of Early Childhood Research, 4(2), 169-188

Chen, J., \& Chang, C. (2010). A comprehensive approach to technology training for early childhood teachers. Early Education \& Development, 17(3), 443-465.

Coffey, A., \& Atkinson, P. (1996). Making sense of qualitative data. London: Sage.

Cuban, L., Kirkpatrick, H. \& Peck, C. (2001). High access and low use of technologies in high school classrooms: Explaining an apparent paradox. American Educational Research Journal, 38(4), 813-834.

Danielson, C. (2007). Enhancing professional practice: A framework for teaching ( $2^{\text {nd }}$ ed.). Alexandria, VA: ASCD.

Darling-Hammond, L. (Eds.). (2005). Preparing teachers for a changing world: What teachers should learn and be able to do. San Francisco, CA: Jossey-Bass.

Darling-Hammond, L., \& Bransford, J. (2005). Preparing teachers for a changing world: What teachers should learn and be able to do. San Francisco: Jossey-Bass.

Dinh, H. T. B. (2009). Factors influencing EFL novice teachers' adoption of technologies in classroom practice. Proceedings from CAMTESOL $5^{\text {th }}$ 2009: Phnom Penh, Cambodia.

Flanagan, L., \& Jacobsen, M. (2003). Technology leadership for the twenty-first century principal. Journal of educational administration, 41(2), 124-142.

Gao, P., Wong, F. L., Choy, D., \& Wu, J. (2010). Developing leadership potential for technology integration: Perspectives of three beginning teachers. Australasian Journal of Educational Technology, 26(5), 643-658.

Gao, P., Wong, F. L., Choy, D., \& Wu, J. (2011). Beginning teachers' understanding performances of technology integration. Asia Pacific Journal of Education, 31(2), 211- 223.

Harper, D. (2006). An argument for visual sociology. In J. Prosser (ed.), Image-based research: A sourcebook for qualitative researchers (24-41). New York: Routledge Falmer.

Huberman, A. M., \& Miles, M. B. (1994). Data management and analysis methods. In N.K. Denzin \& Y.S. Lincoln (Eds.), Handbook of qualitative research (pp. 428-444). Thousand Oaks, CA: Sage.

Illinois Interactive Report Card. (2011). Achievement Gap Groups [Data file]. Retrieved from http://iirc.niu.edu/School.aspx?source=Test_Results\&source2=Achievement_Gap

International Society for Technology in Education (ISTE) (2000). ISTE National Educational Technology Standards (NETS) and Performance Indicators for Teachers. Retrieved from http://www.iste.org/docs/pdfs/nets_for_teachers_2000.pdf?sfvrsn=2 
Jenkins, B. (2009). What It Takes to Be an Instructional Leader. Principal, 88(3), 34-37. Retrieved from http://www.naesp.org/resources/2/Principal/2009/J-F_p34.pdf

Johnson, R. B. (1997). Examining the validity structure of qualitative research. Education, $118,282-292$.

Kay, R. H. (2006). Evaluating strategies used to incorporate technology into preservice education: A review of the literature. Journal of Research on Technology in Education, 38(4), 385-410.

Lunenburg, F. C., \& Irby, B. J. (2006). The principalship: Vision to action. Belmont, CA: Wadsworth.

Lunenburg, F. C., \& Ornstein, A. O. (2008). Educational administration: Concepts and practices (5th ed.). Belmont, CA: Wadsworth/Cengage.

Marzano, R. J. (2003). What works in schools: Translating research into action. Alexandria, VA: Association for Supervision and Curriculum Development

Mayo, N. B., \& Kajs, L.T. (2005). Longitudinal study of technology training to prepare future teachers. Educational Research Quarterly, 29(1), 3-15.

Merriam, S. B. (2009). Qualitative research: A guide to design and implementation. San Francisco: Jossey-Bass.

National Center for Education Statistics (2000). Teachers' tools for the $21^{\text {st }}$ century: A report on teachers' use of technology. Jessup, MD: US Department of Education.

National Educational Technology Plan. (2010). Transforming American education: Learning powered by technology. Washington, DC: U.S. Department of Education.

O'Connor, E. A. (2006-2007). A case study of the approach to teaching and to technology of three new teachers in an alternative teacher certification program. Journal of Educational Technology Systems, 35(3), 357-382.

Patton, M. Q. (1990). Qualitative evaluation and research methods (2nd ed.). Newbury Park, CA: Sage Publications.

Pritchard, K. (2014). Recommendations for K-12 administrators for technology integration. In M. Searson \& M. Ochoa (Eds.), Proceedings of Society for Information Technology \& Teacher Education International Conference 2014 (pp. 957-961). Chesapeake, VA: AACE.

Rogers, B. A. (2000). The correlation between teachers' perceptions of principals' technology leadership and the integration of educational technology (Unpublished doctoral dissertation). Ball State University, Indiana.

Russell, M., Bebell, D., O’Dwyer, L., \& O’Connor, K. (2003). Examining teacher technology use: Implications for pre-service and in-service teacher preparation. Journal of Teacher Education, 54(4), 297-310.

Starkey, L. (2010). Supporting the digitally able beginning teacher. Teaching and Teacher 
Education, 26, 1429-1438.

Stewart, J. (2006). Transformational leadership: An evolving concept examined through the works of Burns, Bass, Avolio, and Leithwood. Canadian Journal of Educational Administration and Policy, 54, 1-29.

Waring, S. M. (2010). The impact of a technology coordinator's belief system upon using technology to create a community's history. Computers in the Schools, 27, 76-98.

Williams, M. K., Foulger, T. S., \& Wetzel, K. (2009). Preparing preservice teachers for $21^{\text {st }}$ century classrooms: Transforming attitudes and behaviors about innovative technology. Journal of Technology and Teacher Education, 17(3), 393-418.

\section{Appendix}

Photographs of educational technology devices and facilities available to first-year teachers

\section{School \#1:}

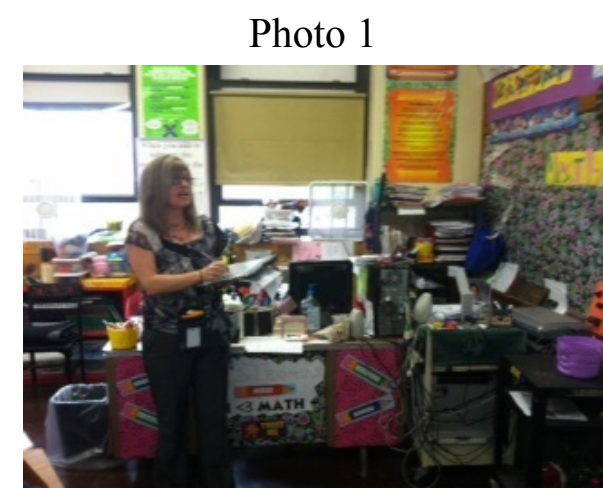

Photo 1: Mathematics instructor using Airliner technology to wirelessly interact with SMART board, while saving notes and data to hard drive.

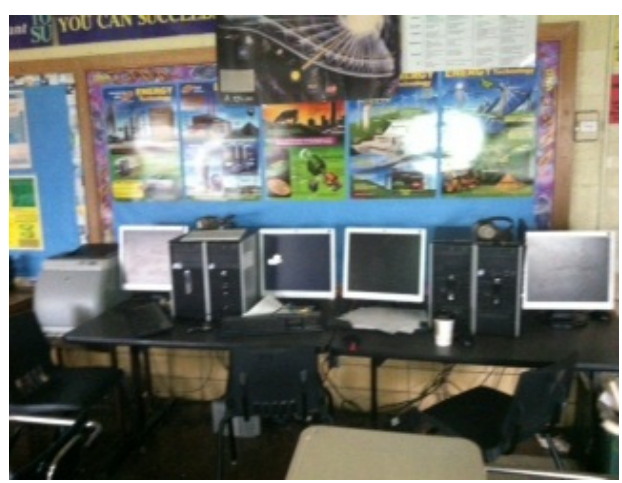

Photo 3: Typical desktop computer arrangement in classroom
Photo 2

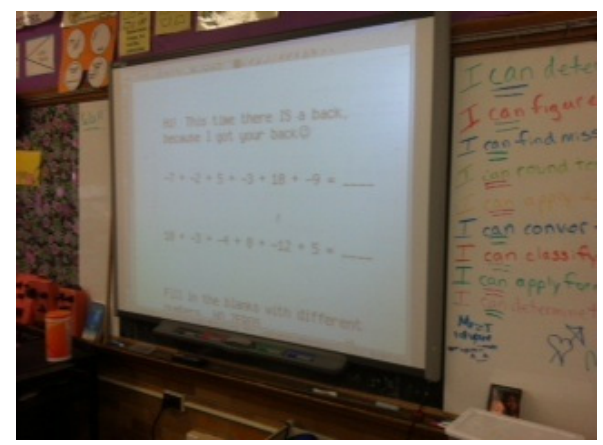

Photo 2: SMART board technology interactive, digital whiteboard being used in Mathematics instruction

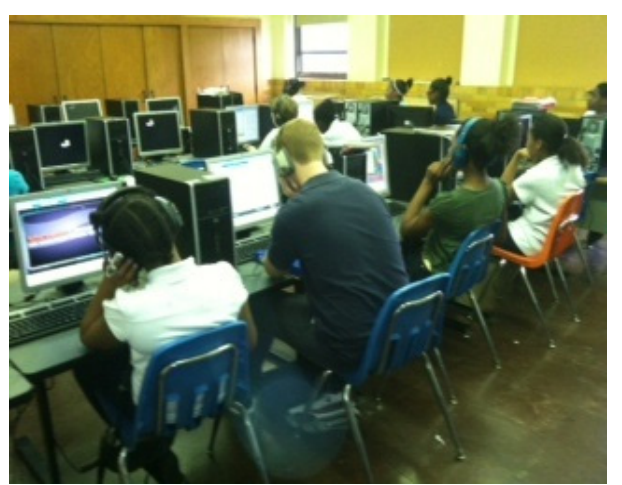

Photo 4: Computer Lab - designated for Compass Learning - differentiated learning through diversified curriculum \& assessments 


\section{Macrothink}

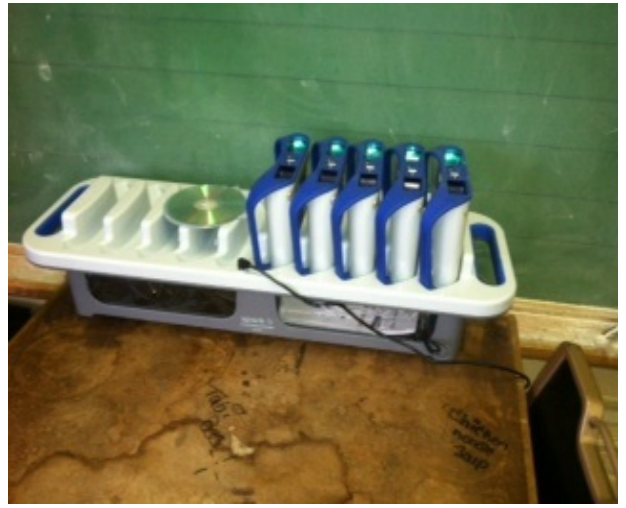

Photo 5: SPARKvue Science Learning Center - Real time data collection and graphing software

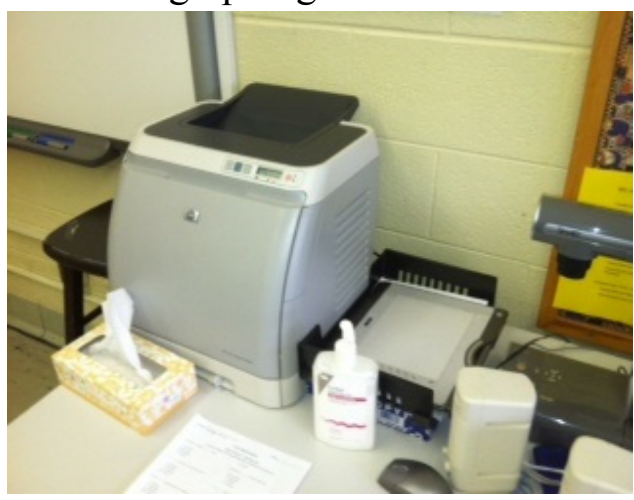

Photo 7: Printer connected to teacher computer
Journal of Education and Training

ISSN 2330-9709

2015, Vol. 2, No. 1

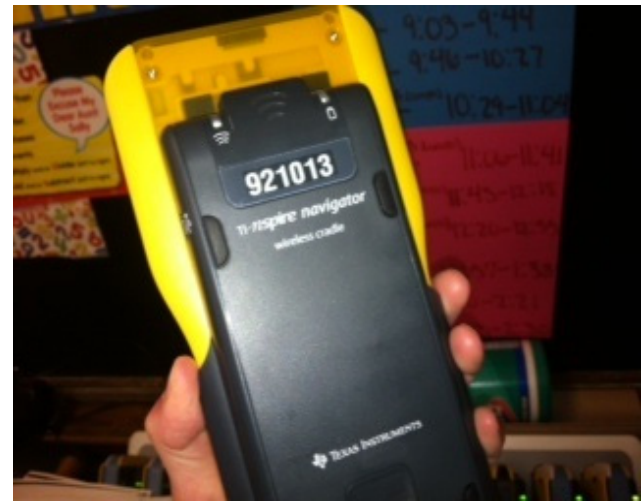

Photo 6: Texas Instruments Navigator

Calculators - Wirelessly networking students' calculators to teacher computers

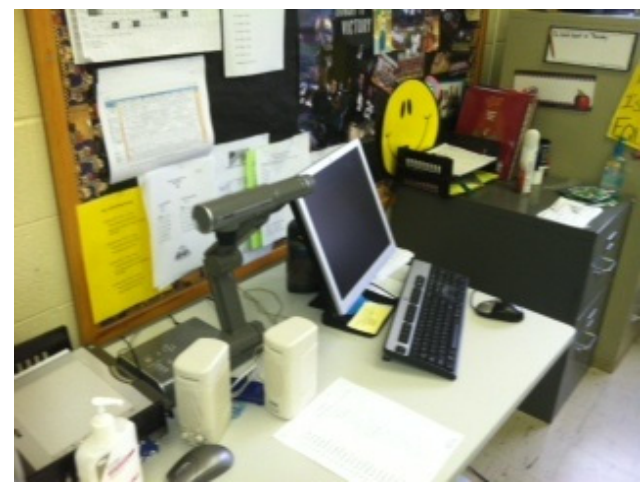

Photo 8: ELMO document camera - 3 dimensional image projectors

\section{School \#2:}

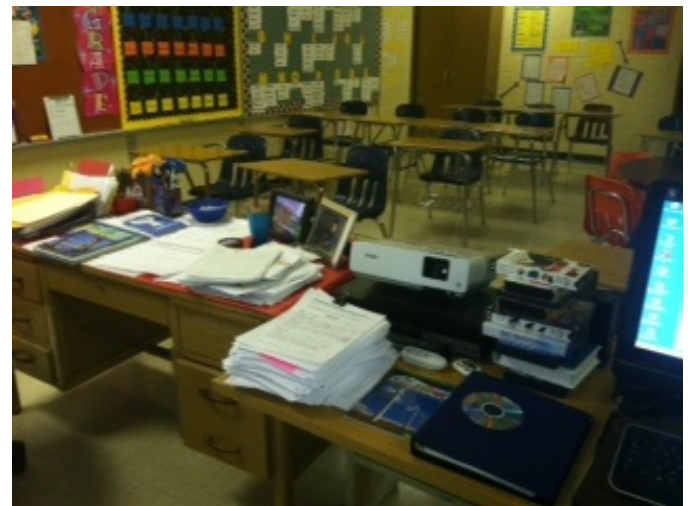

Photo 1: Typical classroom LCD projector

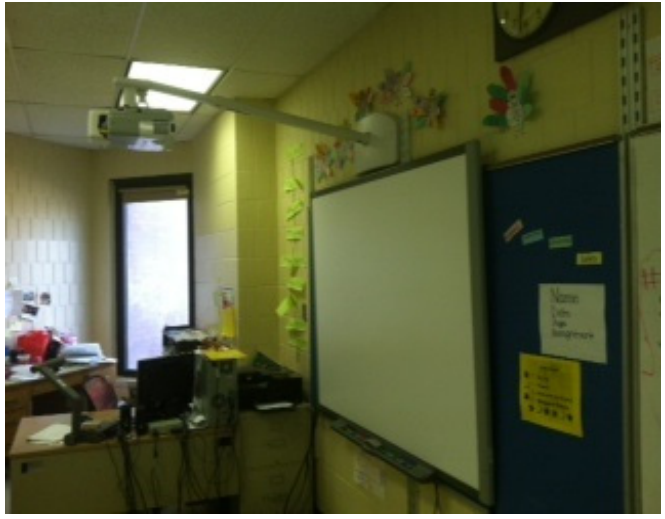

Photo 2: SMART board with wall mounted LCD projector 


\section{$\Lambda$ Macrothink}

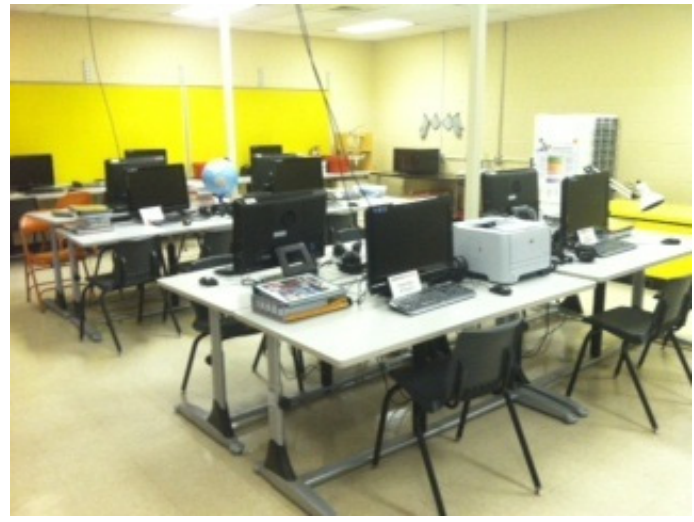

Photo 3: Computer Lab

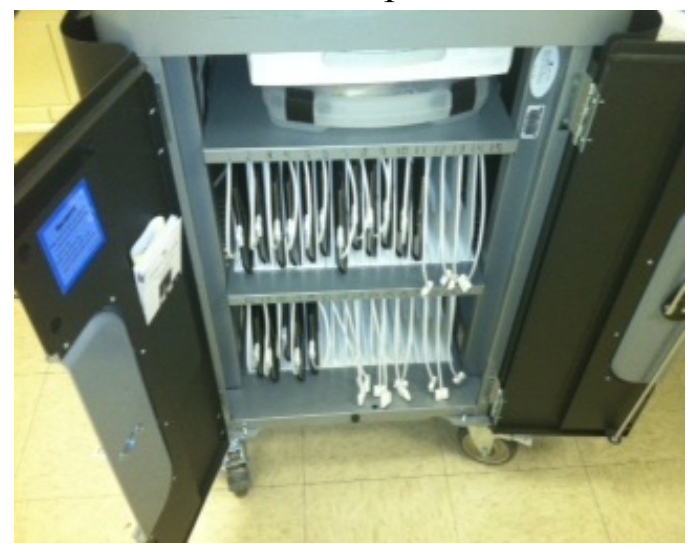

Photo 5: iPad mobile cart

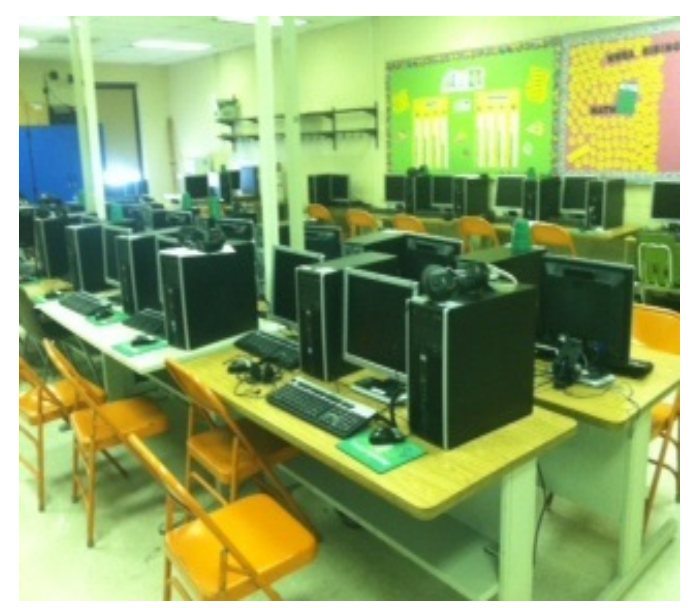

Photo 7: Computer Lab
Journal of Education and Training

ISSN 2330-9709 2015, Vol. 2, No. 1

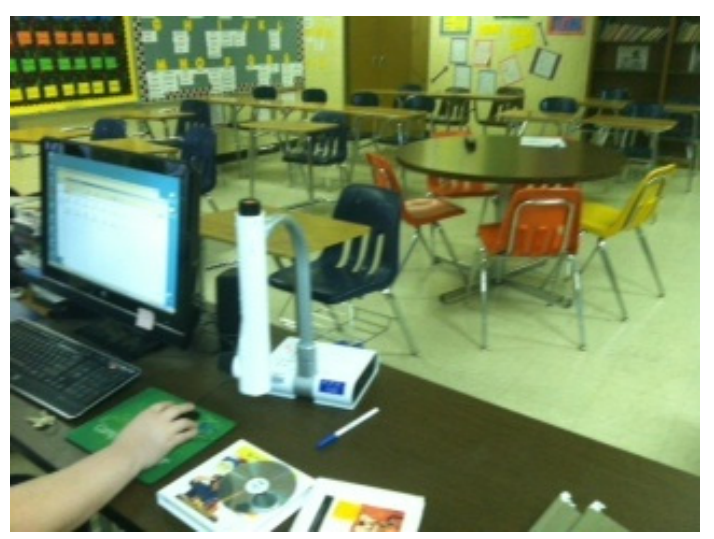

Photo 4: Document analysis camera - ELMO

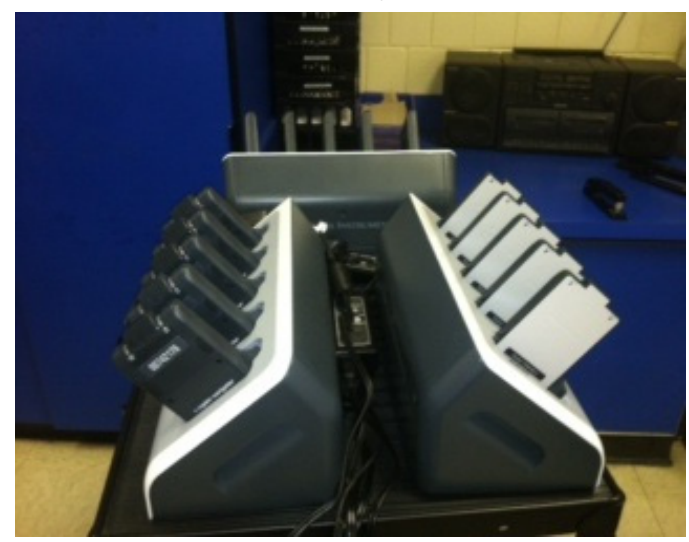

Photo 6: Texas Instruments INSPIRE graphic calculators

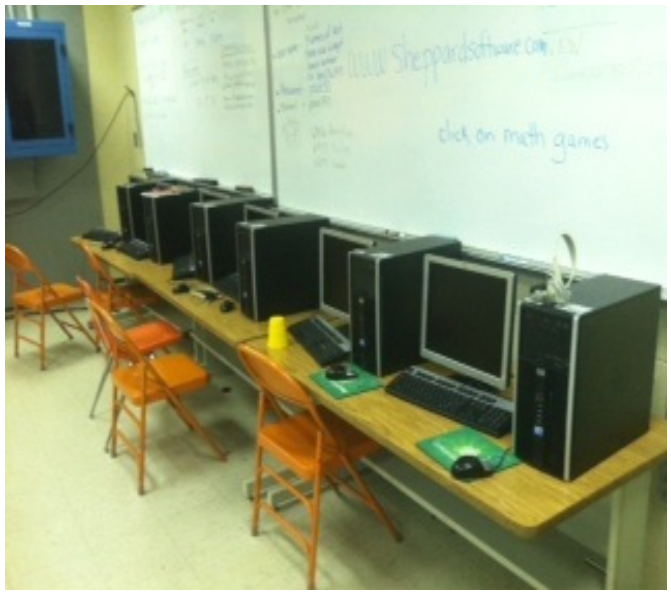

Photo 8: Side wall of computer lab 


\section{Macrothink Institute $^{\text {TM }}$}

\section{School \#3:}

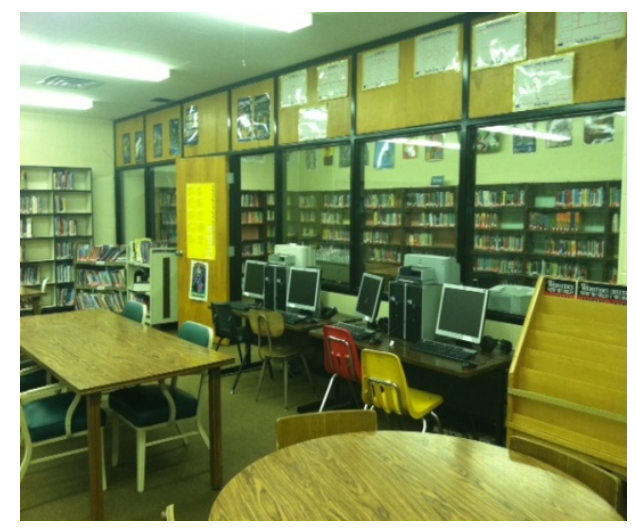

Photo 1: Computers held in library

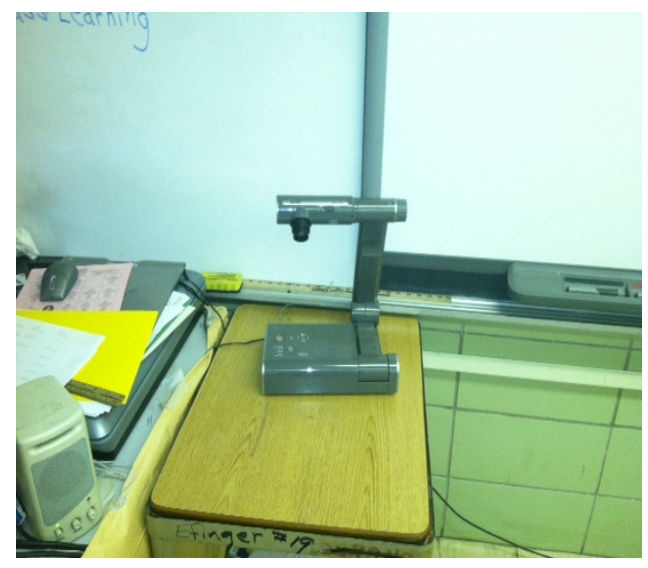

Photo 3: ELMO document camera

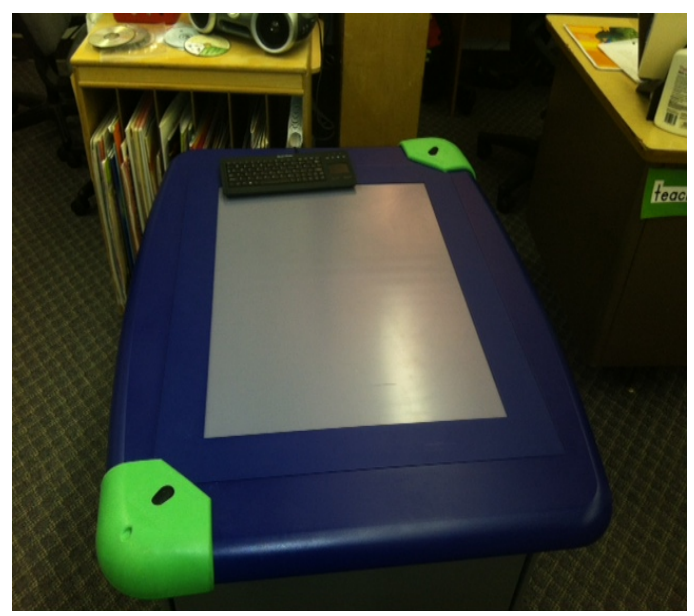

Photo 5: SMART table in preschool room
Journal of Education and Training

ISSN 2330-9709

2015, Vol. 2, No. 1

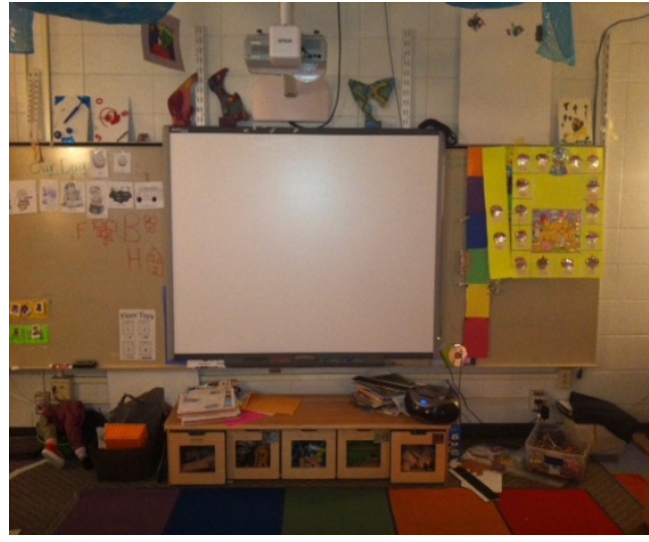

Photo 2: SMART board and projector held in preschool room

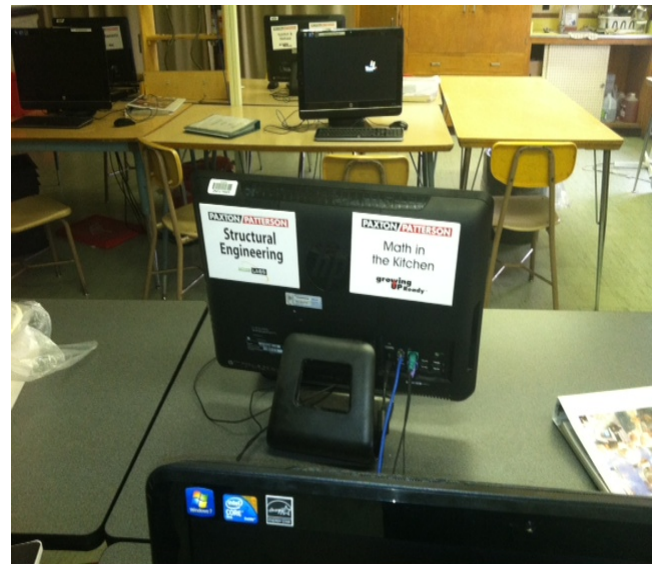

Photo 4: Paxton/Patterson project-based learning lab

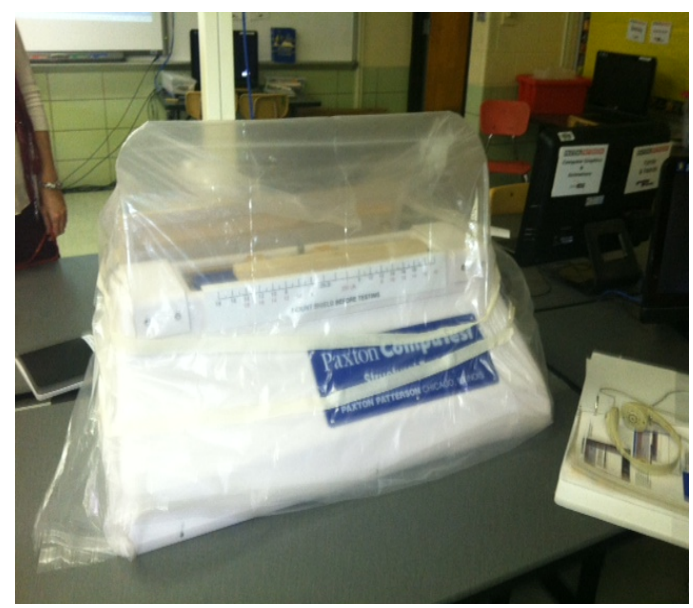

Photo 6: Paxton/Patterson project based learning lab - digital scale 


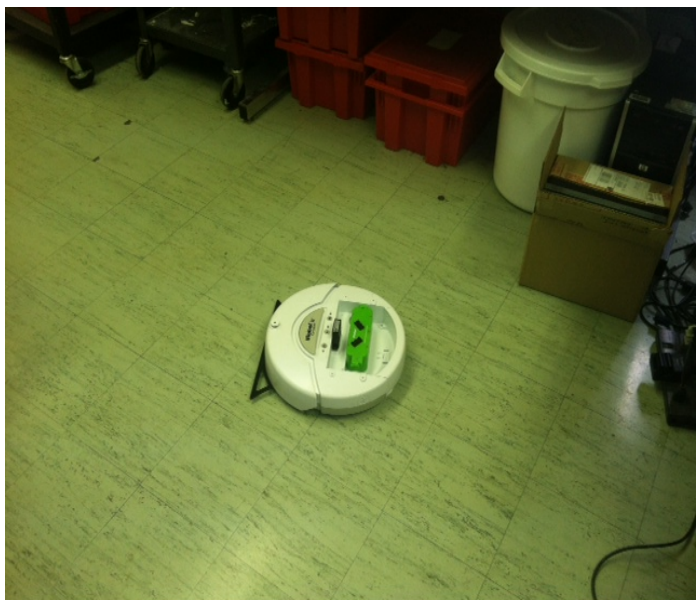

Photo 7: irobot - cleaning purposes

\section{School \#4:}

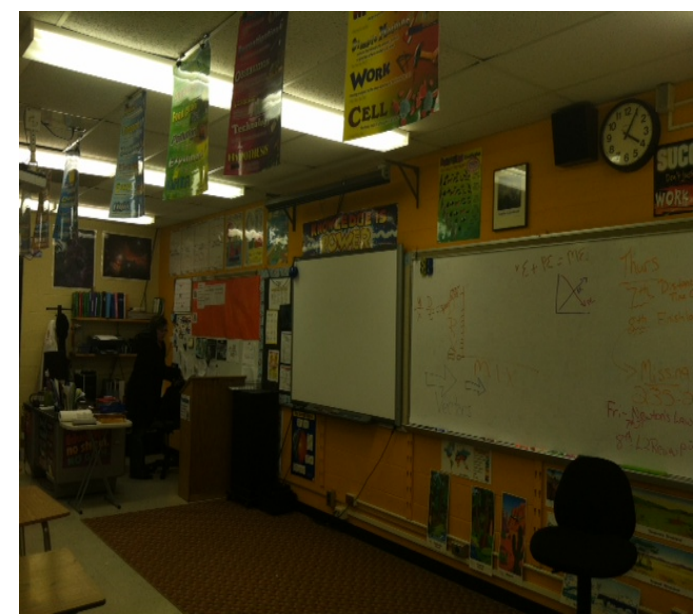

Photo 1: STEM classroom - SMART board

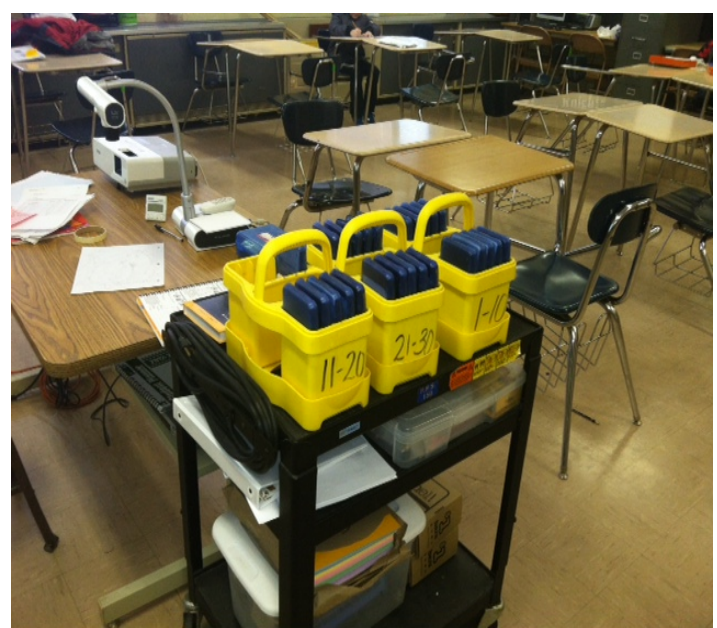

Photo 3: TI INSPIRE graphic calculators

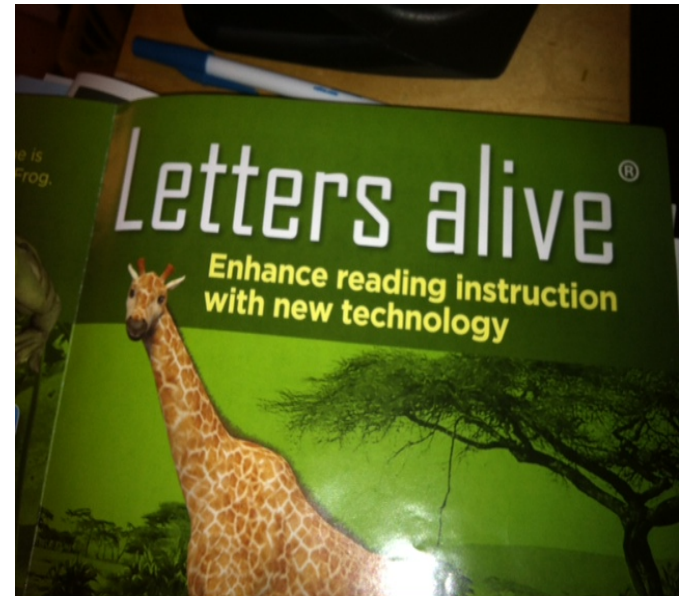

Photo 8: Letters Alive 3D augmented reality reading program

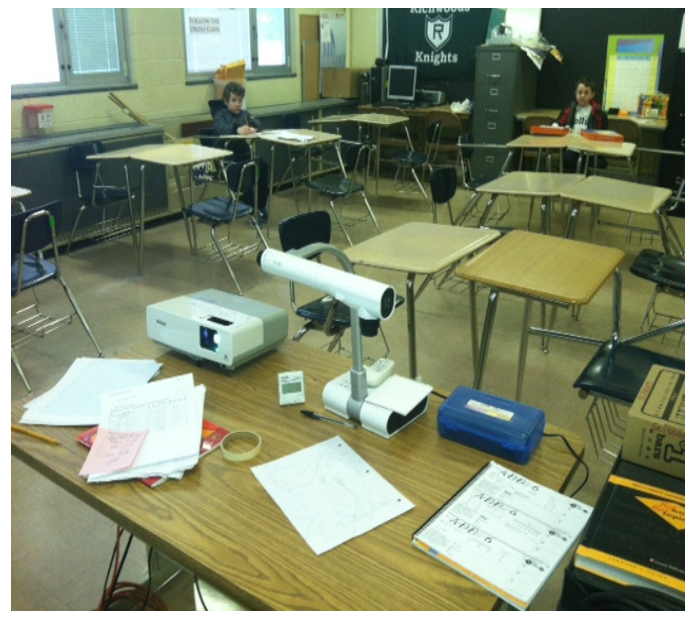

Photo 2: ELMO document camera

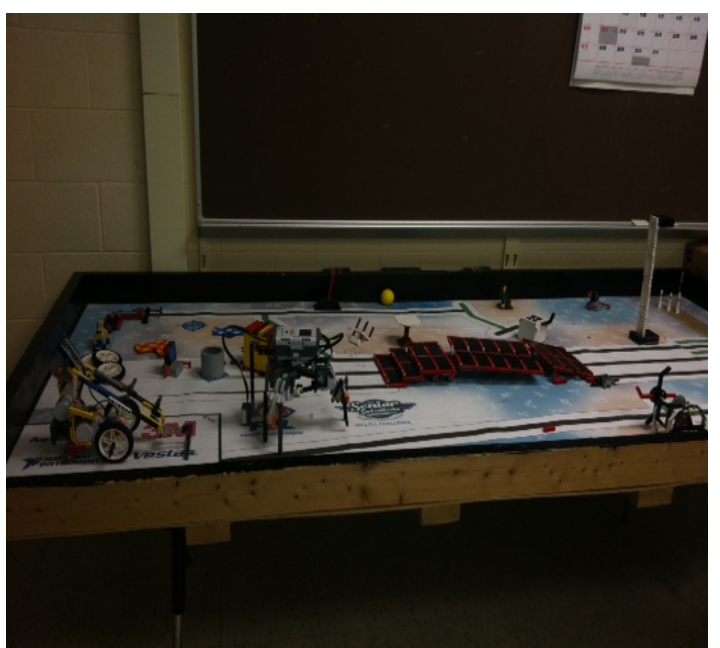

Photo 4: LEGO Mindstrom Robotics table 


\section{I Macrothink}

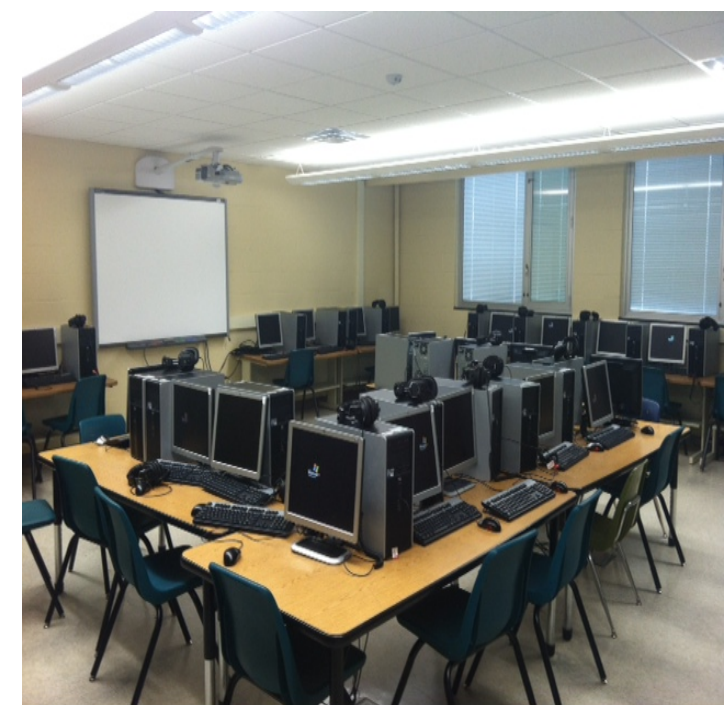

Photo 5: Computer lab

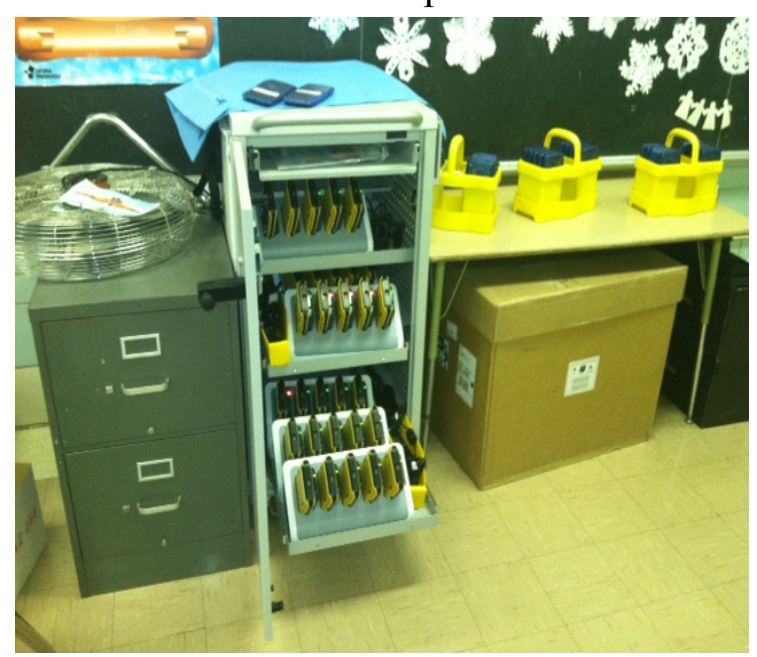

Photo 7: TI INSPIRE graphic calculators
Journal of Education and Training

ISSN 2330-9709

2015, Vol. 2, No. 1

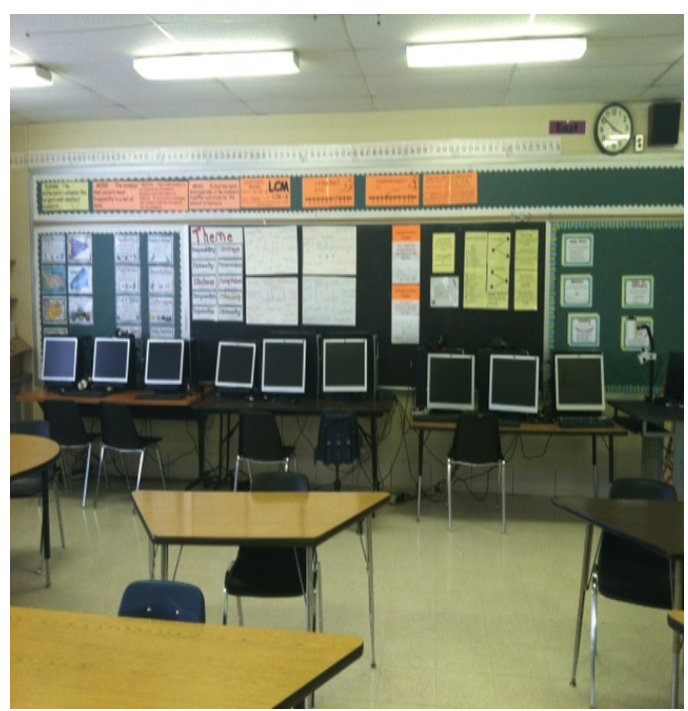

Photo 6: Computers held in math classroom

\section{Copyright Disclaimer}

Copyright reserved by the author(s).

This article is an open-access article distributed under the terms and conditions of the Creative Commons Attribution license (http://creativecommons.org/licenses/by/3.0/). 